\title{
Technical challenges and solutions in a closed loop MEG regeneration system for gas field offshore, UK
}

\author{
S. Baraka-Lokmane ${ }^{1}$, Ch. Hurtevent ${ }^{1}$, M. Seiersten ${ }^{2}$, E. Flaten ${ }^{2}$, \\ M. Farrell ${ }^{3}$, O. Bradshaw ${ }^{3}$, S. Hare ${ }^{3}$, M. Bonis ${ }^{1}$, F. Jacob ${ }^{1}$ \\ \& N. Carles ${ }^{1}$ \\ ${ }^{1}$ TOTAL, France \\ ${ }^{2}$ Institute for Energy Technology (IFE), Norway \\ ${ }^{3}$ TOTAL E\&P UK, UK
}

\begin{abstract}
Two UK gas/condensate fields are being developed as a single integrated subsea production system. Mono Ethylene Glycol (MEG) is used as a thermodynamic hydrate inhibitor. The main processes for recycling of MEG are regeneration and reclamation. Operational problems within closed MEG system are carbonate $\left(\mathrm{CaCO}_{3}\right)$ scaling deposits at MEG injection point, pipeline, and salt removal system as well as accumulation of corrosion products. This paper presents the results of prediction of precipitation of solids and corrosion in the closed MEG loop system and presents solutions for these challenges. The key points discussed in this paper are (i) The choice of acid to be used to neutralise excess alkalinity in the Lean MEG; (ii) The upper limit value of $\mathrm{pH}$ in order to keep a low corrosion rate and prevent scaling risk; (iii) The risk and consequences of $\mathrm{HCl}$ overdosage; (iv) The location of the injection point of this acid; (v) Calculation of the acid flowrate; (vi) The choice of the alkalinity source required to precipitate the divalent cations in the rich MEG pre-treatment; (vii) Calculation of the flowrate of this alkalinity source; and (viii) Monitoring of alkalinity and acid injection. The modeling methodology used as a basis for this study is a purely thermodynamic approach. The equilibrium calculations are done with the MultiScale software with the glycol add-in.

Keywords: scale, monoethylene glycol, alkalinity, corrosion, hydrochloric acid, sodium carbonate.
\end{abstract}




\section{Introduction}

Reservoir A and Reservoir B gas condensate fields are situated in the UKCS West of Shetland. They are being developed as a single integrated Subsea Production System.

Formation waters from the reservoirs are not available. The composition of aquifer water has been used to estimate the composition of the formation water from Reservoir A; Reservoir B formation water is assumed to be the same. The use of Mono Ethylene Glycol (MEG) for hydrate inhibition in gas production lines is well established and works effectively as long as the salt solubility is not exceeded. MEG is injected in high concentrations, higher than $85 \mathrm{wt} \%$.

The objectives of the study were to:

- Evaluate the risk of mineral scaling from bottom hole to well head taking into account the provided formation water composition which has been used as the basis throughout the project design, as well as analogous formation waters from reservoirs close to reservoirs A and B.

- Evaluate the risk of mineral scaling inside the MEG units.

- Study the effect of Lean MEG specifications on the risk of scaling, especially carbonate scaling.

- Suggest Lean MEG specifications (salinity, bicarbonates, and calcium levels).

Depending on the reservoir, oilfield brines can be saturated with respect to calcite or gypsum, anhydrite and barite. MEG in water lowers the solubility of carbonates and sulphates [1-3]. The effect is most pronounced for sulphates (barite, gypsum and anhydrite) [3]. It is documented that MEG enhances barite scale problems at some conditions [4]. However, depending on temperature and the actual supersaturation, crystal nucleation and growth of barium sulphate can be delayed for long period of time [4]. The solubility of $\mathrm{CaSO}_{4}$ decreases with MEG concentration [1]. Another thermodynamic effect is that anhydrite is observed at lower temperature in MEG solutions due to the lower water activity [4]. In contrast to $\mathrm{CaSO}_{4}$, the effect of MEG on the solubility of $\mathrm{CaCO}_{3}$ is small [1, 3]. When a $\mathrm{CaCO}_{3}$ saturated brine is mixed with pure MEG, the dilution counteracts reduced solubility at most conditions [5, 6]. Furthermore, MEG decreases the nucleation growth rates of the calcium carbonate isomorphs. The effect is most pronounced at low temperature $[2,7]$.

\section{Process overview}

The MEG Regeneration system comprises three modules: pre-treatment module, regeneration module and desalination module. An overview of the MEG loop used in the simulation work is shown in Figure 1. 


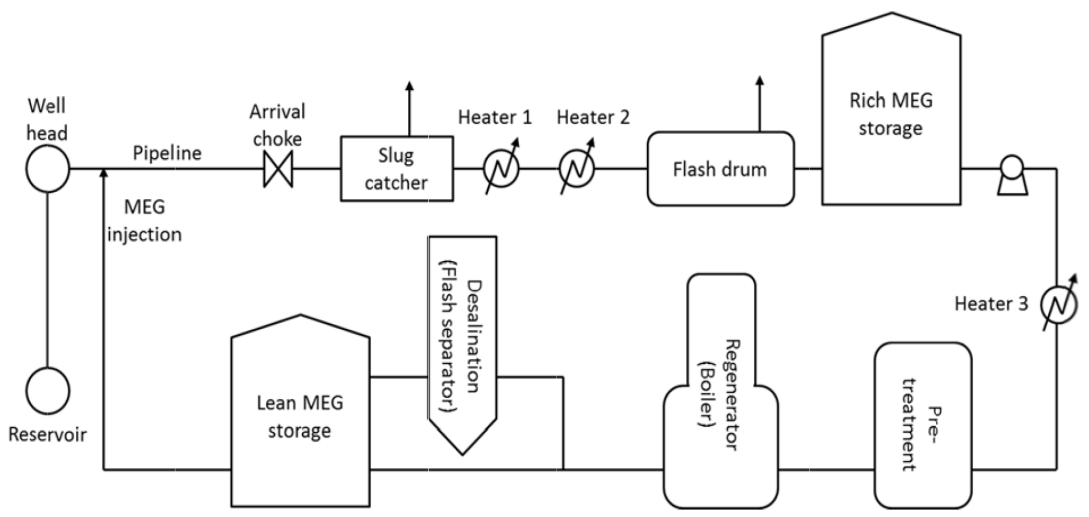

Figure 1: $\quad$ Schematic overview of the MEG loop used in the simulation work.

\section{Operating procedure}

For the evaluation of the risk of scaling from bottom hole to well head for the two reservoirs, as well as for the sensitivity study using formation waters representative of other West of Shetland reservoirs, three software packages have been used; these are SCALE 2000 v.3.1, ScaleSoftPitzer and MultiScale. Software package MultiScale has been used to evaluate the scaling risk of scaling from bottom hole to well head, as well as inside the MEG loop. All three give purely thermodynamic predictions; they do not model nucleation and growth rates.

SCALE 2000 v.3.1 has been developed by BRGM, France. ScaleSoftPitzer has been developed by Rice University, United States. MultiScale has been developed by the Norwegian University of Science and Technology (NTNU). SCALE 2000 and ScaleSoftPitzer software work as a point simulation. The present version of MultiScale has been developed by NTNU in a project supported by Statoil and Norsk Hydro. Multiscale model is also a point simulation tool, but with a process module that makes it possible to use the output from the calculation at one point as input in the next point.

Saturation Ratio (SR) is used to quantify the thermodynamic driving force for precipitation and hence scaling risk. It is calculated from bottom hole to well head, and inside the MEG loop. As a general rule, the risk of scaling is predicted by the Saturation Ratio (SR) as the following criteria:

- If $\mathrm{SR}>1$, the water is oversaturated and salt might potentially precipitate.

- $\quad$ At $\mathrm{SR}=1$, the water is at equilibrium.

- $\quad$ If $\mathrm{SR}<1$, the water is under-saturated and scaling cannot occur.

Whether a salt actually precipitates at $\mathrm{SR}>1$ depends on the nucleation and growth rate. However, the higher the Saturation Ratio, the faster the kinetics of precipitation. Generally, the SR required for precipitation onset decreases with 
temperature. The simulation reported herein is based on the following assumptions and adjustments:

1. All reactions reach thermodynamic equilibrium.

2. Formation water tuning and adjustments:

- The alkalinity is tuned to give $\mathrm{CaCO}_{3}$ saturation at reservoir conditions with the calcium concentration given in the formation water analysis.

- The organic acid concentration in the produced water is tuned to saturation with the tuned alkalinity.

- The concentration of sulphate is tuned to give saturation of $\mathrm{BaSO} 4$ at reservoir conditions.

- The concentration of chloride is adjusted to give electro neutrality.

3. Any precipitated salts (mainly divalent least soluble salts) from Rich MEG are left behind and not carried with the Rich MEG from rich MEG pretreatment to the Lean MEG storage tank.

4. Precipitated solids (monovalent and divalent salts) are carried through from the pipeline to the pre-treatment.

5. The condensed water rate is set to water saturation of the gas at bottom hole conditions.

6. Slip stream to desalination is calculated as \% of Lean MEG Mass Rate including salts (monovalent and divalent salts).

7. $\mathrm{Na}_{2} \mathrm{CO}_{3}$ injection in pre-treatment is tuned to precipitate all divalent cations to concentration less than $1 \mathrm{mg} / \mathrm{kg}$ solvent.

8. $\mathrm{HCl}$ injection in Lean MEG is tuned to neutralise alkalinity that forms $\mathrm{HCO}_{3}^{-}$("strong alkalinity") when balanced with the produced liquid phase (i.e. $\mathrm{OH}^{-}, \mathrm{CO}_{3}^{2-}$ and $\mathrm{HCO}_{3}^{-}$). That implies that organic acids are kept as carboxylates.

\section{Scaling prediction from bottom hole to well head}

Table 1 presents the analysis points from bottom hole to the Lean MEG storage. The composition of the formation water for Reservoir A has been estimated from the composition of formation water from Reservoir B; consequently, the concentrations of individual ions of Reservoir A water are very approximate (Table 2). The organic acids were counted as $60 \mathrm{mg} / \mathrm{kg}$ total acetic acid, i.e. HAc $+\mathrm{Ac}^{-}=60 \mathrm{mg} / \mathrm{kg}$. Three formation waters from reservoirs close to Reservoir A and Reservoir B (Reservoirs C, D and E) have been tested (Table 2). The simulations performed with waters from reservoirs A, C, D and E show that there is no risk of calcium carbonate, barium sulphate and calcium sulphate scaling from bottom hole to well head (Table 3). 
Table 1: $\quad$ Analysis points from bottom hole to the Lean MEG storage.

\begin{tabular}{|c|c|c|c|c|}
\hline & \multicolumn{2}{|c|}{ Reservoir A } & \multicolumn{2}{|c|}{ Reservoir B } \\
\hline & Pressure (bara) & Temperature $\left({ }^{\circ} \mathrm{C}\right)$ & Pressure (bara) & Temperature $\left({ }^{\circ} \mathrm{C}\right)$ \\
\hline Reservoir & 431 to 70 & 112 & 418 to 99 & 118 \\
\hline Bottom hole & 412 to 63 & 112 & 400 to 92 & 118 \\
\hline $\begin{array}{l}\text { Upstream } \\
\text { well head }\end{array}$ & 351 to 41 & 83 to 43 & 157 to 43 & 83 to 52 \\
\hline \multirow[t]{2}{*}{$\begin{array}{l}\text { downstream } \\
\text { well head }\end{array}$} & 351 to 41 & 74 to 34 & 157 to 43 & 74 to 43 \\
\hline & \multicolumn{2}{|c|}{ Pressure (bara) } & \multicolumn{2}{|c|}{ Temperature $\left({ }^{\circ} \mathrm{C}\right)$} \\
\hline $\begin{array}{c}\text { MEG } \\
\text { injection }\end{array}$ & \multicolumn{2}{|c|}{541 to 41} & \multicolumn{2}{|c|}{74 to 43} \\
\hline Pipeline & \multicolumn{2}{|c|}{125 to 42} & \multicolumn{2}{|c|}{-1 to 50} \\
\hline Slugcatcher & \multicolumn{2}{|c|}{29 to 10} & \multicolumn{2}{|c|}{-8 to 12} \\
\hline Heater 1 & \multicolumn{2}{|c|}{25.1 to 6} & \multicolumn{2}{|c|}{16.9 to 1.6} \\
\hline Heater 2 & \multicolumn{2}{|c|}{24 to 4} & \multicolumn{2}{|c|}{41 to 40} \\
\hline Flash Drum & \multicolumn{2}{|c|}{1.5} & \multicolumn{2}{|c|}{41} \\
\hline $\begin{array}{l}\text { Rich MEG } \\
\text { storage }\end{array}$ & \multicolumn{2}{|c|}{1} & \multicolumn{2}{|c|}{-7 to 40} \\
\hline Heater 3 & \multicolumn{2}{|c|}{2.5} & \multicolumn{2}{|c|}{60} \\
\hline $\begin{array}{l}\text { MEG Pre- } \\
\text { treatment - } \\
\text { Filter press }\end{array}$ & \multicolumn{2}{|c|}{2.5} & \multicolumn{2}{|c|}{60} \\
\hline $\begin{array}{c}\text { MEG } \\
\text { Regeneration } \\
\text { column }\end{array}$ & \multicolumn{2}{|c|}{0 to 2.5} & \multicolumn{2}{|c|}{156} \\
\hline $\begin{array}{l}\text { Lean MEG } \\
\text { storage }\end{array}$ & \multicolumn{2}{|c|}{1} & \multicolumn{2}{|c|}{30} \\
\hline
\end{tabular}

Table 2: Water compositions of formation waters of reservoirs A, C, D and $\mathrm{E}$.

\begin{tabular}{|c|c|c|c|c|}
\hline Ions & $\begin{array}{c}\text { Reservoir A } \\
(\mathrm{mg} / \mathrm{l})\end{array}$ & $\begin{array}{c}\text { Reservoir C } \\
(\mathrm{mg} / \mathrm{l})\end{array}$ & $\begin{array}{c}\text { Reservoir D } \\
(\mathrm{mg} / \mathrm{l})\end{array}$ & $\begin{array}{c}\text { Reservoir E } \\
(\mathrm{mg} / \mathrm{l})\end{array}$ \\
\hline Sodium & 9732 & 9000 & 10880 & 10890 \\
\hline Potassium & 544 & 200 & 258 & 460 \\
\hline Calcium & 4597 & 250 & 215 & 919 \\
\hline Magnesium & 101 & 50 & 24 & 23 \\
\hline Barium & 5 & 60 & 135 & 5 \\
\hline Strontium & 33 & 25 & 53 & 35 \\
\hline Total iron & 8 & 0 & 3 & Not reported \\
\hline Chloride & 23550 & 14300 & 17340 & 9080 \\
\hline Sulphate & 154 & 0 & 2 & 31 \\
\hline Bicarbonate & 168.29 & 1050 & 1255 & 559 \\
\hline $\begin{array}{c}\text { Total dissolved } \\
\text { solids }\end{array}$ & 40000 & 24935 & 30186 & Not reported \\
\hline
\end{tabular}


Table 3: Summary of results of calculation for the streams from the individual field for the Well heads (MEG injection point) and upstream.

\begin{tabular}{|c|c|c|c|c|c|c|c|c|}
\hline & \multicolumn{2}{|c|}{ Reservoir } & \multicolumn{2}{|c|}{ Bottom hole } & \multicolumn{2}{|c|}{ U/S Well Head } & \multicolumn{2}{|c|}{ Well head } \\
\hline & $\begin{array}{c}\text { Reservoir } \\
\text { A }\end{array}$ & $\begin{array}{c}\text { Reservoir } \\
\text { B }\end{array}$ & $\begin{array}{c}\text { Reservoir } \\
\text { A }\end{array}$ & $\begin{array}{c}\text { Reservoir } \\
\text { B }\end{array}$ & $\begin{array}{c}\text { Reservoir } \\
\text { A }\end{array}$ & $\begin{array}{c}\text { Reservoir } \\
\text { B }\end{array}$ & $\begin{array}{c}\text { Reservoir } \\
\text { A }\end{array}$ & $\begin{array}{c}\text { Reservoil } \\
\text { B }\end{array}$ \\
\hline Water & \multicolumn{8}{|c|}{ Reservoir A formation water } \\
\hline $\begin{array}{l}\mathrm{SR} \\
\mathrm{CaCO}_{3}\end{array}$ & 1.00 & 1.00 & 1.02 & 1.02 & 0.74 & 0.84 & 0.64 & 0.70 \\
\hline $\begin{array}{l}\mathrm{SR} \\
\mathrm{BaSO}_{4}\end{array}$ & 1.02 & 1.00 & 1.03 & 1.01 & 1.25 & 1.39 & 1.34 & 1.54 \\
\hline $\begin{array}{l}\mathrm{SR} \\
\mathrm{CaSO}_{4}\end{array}$ & 0.68 & 0.73 & 0.69 & 0.74 & 0.51 & 0.57 & 0.46 & 0.50 \\
\hline Water & \multicolumn{8}{|c|}{ Reservoir C formation water } \\
\hline $\begin{array}{l}\mathrm{SR} \\
\mathrm{CaCO}_{3}\end{array}$ & 1.00 & 1.00 & 1.02 & 1.02 & 0.66 & 0.90 & 0.56 & 0.73 \\
\hline $\begin{array}{l}\mathrm{SR} \\
\mathrm{BaSO}_{4}\end{array}$ & 0.12 & 0.12 & 0.12 & 0.12 & 0.14 & 0.16 & 0.15 & 0.17 \\
\hline $\begin{array}{l}\mathrm{SR} \\
\mathrm{CaSO}_{4} \\
\end{array}$ & 0.00 & 0.00 & 0.00 & 0.00 & 0.00 & 0.00 & 0.00 & 0.00 \\
\hline Water & \multicolumn{8}{|c|}{ Reservoir D formation water } \\
\hline $\begin{array}{l}\mathrm{SR} \\
\mathrm{CaCO}_{3}\end{array}$ & 1.00 & 1.00 & 1.02 & 1.02 & 0.66 & 0.90 & 0.56 & 0.73 \\
\hline $\begin{array}{l}\mathrm{SR} \\
\mathrm{BaSO}_{4}\end{array}$ & 0.12 & 0.80 & 1.12 & 0.80 & 0.14 & 1.07 & 0.15 & 1.19 \\
\hline $\begin{array}{l}\mathrm{SR} \\
\mathrm{CaSO}_{4}\end{array}$ & 0.00 & 0.00 & 0.00 & 0.00 & 0.00 & 0.00 & 0.00 & 0.00 \\
\hline Water & \multicolumn{8}{|c|}{ Reservoir E formation water } \\
\hline $\begin{array}{l}\mathrm{SR} \\
\mathrm{CaCO}_{3} \\
\end{array}$ & 1.00 & 1.00 & 1.25 & 1.02 & 0.66 & 0.86 & 0.56 & 0.68 \\
\hline $\begin{array}{l}\mathrm{SR} \\
\mathrm{BaSO}_{4}\end{array}$ & 0.12 & 0.64 & 0.12 & 0.64 & 0.14 & 0.90 & 0.15 & 0.93 \\
\hline $\begin{array}{l}\mathrm{SR} \\
\mathrm{CaSO}_{4}\end{array}$ & 0.00 & 0.07 & 0.00 & 0.07 & 0.00 & 0.05 & 0.00 & 0.05 \\
\hline
\end{tabular}

\section{Precipitation prediction from well head through the process system and the MEG regeneration unit}

The results of the simulations downstream the wellhead through the process system and the MEG Regeneration Unit (MRU) is given in Table 4 and 5. Up to the rich MEG pre-treatment the software is set to carry solids from one point to another. This implies that the amount of solids given at each point is the total amount including the upstream solids. The calculated required $\mathrm{Na}_{2} \mathrm{CO}_{3}$ and $\mathrm{HCl}$ flowrates are presented in Table 5.

The results show risk of precipitation upstream of the MEG recovery unit, but only solid corrosion products are predicted. The SR for $\mathrm{FeCO}_{3}$ exceeds 100 at the pipeline outlet. The total amount of corrosion products and the amount that will follow all the way to the MEG Regeneration Unit (MRU) are uncertain. The predictions are conservative in that the corrosion rate might be high taking the low $\mathrm{CO}_{2}$ concentration into account and it is further anticipated that all corrosion products are produced to the Lean MEG and not left in the pipeline. 
Table 4: $\quad$ Simulations results upstream of the MEG unit.

\begin{tabular}{|c|c|c|c|c|c|c|c|}
\hline & Pipeline & $\begin{array}{l}\text { Slug } \\
\text { Catcher }\end{array}$ & $\begin{array}{l}\text { Heater } \\
1\end{array}$ & $\begin{array}{l}\text { Heater } \\
2\end{array}$ & $\begin{array}{l}\text { Flash } \\
\text { Drum }\end{array}$ & $\begin{array}{l}\text { Rich } \\
\text { MEG } \\
\text { storage } \\
\end{array}$ & $\begin{array}{l}\text { Heater } \\
3\end{array}$ \\
\hline $\begin{array}{l}\text { Pressure } \\
\text { (bara) }\end{array}$ & 124 & 29 & 25.1 & 24 & 1.5 & 1.1 & 2.5 \\
\hline $\begin{array}{l}\text { Temperature } \\
\left({ }^{\circ} \mathrm{C}\right)\end{array}$ & -10 & -8 & 1.6 & 40 & 41 & -7 & 60 \\
\hline $\mathrm{pH}$ & 6.38 & 6.74 & 6.75 & 6.57 & 7.30 & 8.05 & 7.14 \\
\hline Wt\% MEG & 58.27 & 58.30 & 58.30 & 58.30 & 58.49 & 58.49 & 58.48 \\
\hline $\mathrm{CO}_{2(\mathrm{~mol} / \mathrm{kg})}$ & 0.0045 & 0.0021 & 0.0019 & 0.0015 & 0.0001 & 0.0000 & 0.0001 \\
\hline $\begin{array}{l}\text { Alkalinity } \\
\text { (mmol/kg) }\end{array}$ & 5.13 & 5.14 & 5.09 & 3.13 & 2.01 & 2.18 & 1.91 \\
\hline $\begin{array}{l}\text { Density } \\
\left(\mathrm{kg} / \mathrm{m}^{3)}\right.\end{array}$ & 1.09 & 1.09 & 1.09 & 1.09 & 1.09 & 1.09 & 1.09 \\
\hline \multicolumn{8}{|c|}{ Supersaturation ration (SR) } \\
\hline $\mathrm{CaCO}_{3}$ & 0.08 & 0.24 & 0.42 & 2.68 & 35.00 & 199.18 & 154.15 \\
\hline $\mathrm{FeCO}_{3}$ & 0.17 & 0.51 & 1.04 & 11.58 & 152.57 & 436.5 & 764.67 \\
\hline $\mathrm{BaSO}_{4}$ & 6.32 & 6.33 & 6.03 & 3.48 & 3.53 & 6.61 & 2.49 \\
\hline $\mathrm{CaSO}_{4}$ & 0.02 & 0.03 & 0.03 & 0.03 & 0.03 & 0.01 & 0.02 \\
\hline \multicolumn{8}{|c|}{ Precipitation (kg/day) } \\
\hline $\mathrm{CaCO}_{3}$ & 0.00 & 0.00 & 0.00 & 0.00 & 0.00 & 0.00 & 0.00 \\
\hline $\mathrm{FeCO}_{3}$ & 0.00 & 0.00 & 3.07 & 128.87 & 169.60 & 117.93 & 176.21 \\
\hline $\mathrm{BaSO}_{4}$ & 0.02 & 0.02 & 0.02 & 0.02 & 0.01 & 0.02 & 0.01 \\
\hline $\mathrm{CaSO}_{4}$ & 0.00 & 0.00 & 0.00 & 0.00 & 0.00 & 0.00 & 0.00 \\
\hline
\end{tabular}

Table 5: $\quad$ Simulations results in the MEG unit

\begin{tabular}{|c|c|c|c|}
\hline & Pre-treatment & $\begin{array}{l}\text { MEG } \\
\text { regeneration }\end{array}$ & $\begin{array}{l}\text { Lean MEG } \\
\text { storage }\end{array}$ \\
\hline Pressure (bara) & 2.5 & 1.7 & 1.1 \\
\hline Temperature $\left({ }^{\circ} \mathrm{C}\right)$ & 60 & 156 & 30 \\
\hline $\mathrm{pH}$ & 9.81 & 9.34 & 8.12 \\
\hline Wt\% MEG & 56.13 & 88.94 & 90.28 \\
\hline $\mathrm{CO}_{2}(\mathrm{~mol} / \mathrm{kg})$ & 0.000 & 0.000 & 0.000 \\
\hline Alkalinity (mmol/kg) & 14.46 & 20.14 & 0.03 \\
\hline Density $\left(\mathrm{kg} / \mathrm{m}^{3}\right)$ & 1.06 & 1.14 & 1.10 \\
\hline $\begin{array}{l}\mathrm{Na}_{2} \mathrm{CO}_{3}(\mathrm{~mol} / \text { day }) \\
\mathrm{Na}_{2} \mathrm{CO}_{3}\left(\mathrm{~m}^{3} / \text { day }\right)\end{array}$ & $\begin{array}{l}45100 \\
43.32\end{array}$ & & \\
\hline $\begin{array}{l}\mathrm{HCl} \text { (mol/day) } \\
\mathrm{HCl} \text { (L/day) }\end{array}$ & & & $\begin{array}{l}16838 \\
1655\end{array}$ \\
\hline \multicolumn{4}{|c|}{ Supersaturation ration (SR) } \\
\hline $\mathrm{CaCO}_{3}$ & 3375.82 & 0.25 & 0.00 \\
\hline $\mathrm{FeCO}_{3}$ & 71904.87 & 0.05 & 0.00 \\
\hline $\mathrm{BaSO}_{4}$ & 1.69 & 1.33 & 2.08 \\
\hline $\mathrm{CaSO}_{4}$ & 0.02 & 0.27 & 0.01 \\
\hline \multicolumn{4}{|l|}{ Precipitation (kg/day) } \\
\hline $\mathrm{CaCO}_{3}$ & 3459.21 & 0.00 & 0.00 \\
\hline $\mathrm{FeCO}_{3}$ & 213.85 & 0.00 & 0.00 \\
\hline $\mathrm{BaSO}_{4}$ & 0.02 & 0.00 & 0.00 \\
\hline $\mathrm{CaSO}_{4}$ & 0.00 & 0.00 & 0.00 \\
\hline
\end{tabular}

\section{Neutralization of excess alkalinity in the Lean MEG}

Alkalinity in the Lean MEG will increase the risk of calcium carbonate precipitation and possible scale formation in the pipe line at the injection point of Lean MEG due to the relative high concentration of calcium in the formation 
water. Alkalinity in the Lean MEG will increase the $\mathrm{pH}$. The pressure difference across the production choke also enhances the scaling risk. For example, with alkalinity in Lean MEG amounting to $8.9 \mathrm{mmol} / \mathrm{kg}$, the calculated SR (saturation ratio) is equal to 15.32 and precipitation of more than $137 \mathrm{~kg} / \mathrm{d}$ of $\mathrm{CaCO}_{3}$ scale in the MEG injection point is predicted.

To avoid this, it is necessary to neutralize the Lean MEG with an acid in a vessel upstream of the Lean MEG storage tank; this will allow for venting out the $\mathrm{CO}_{2}$ formed when carbonate/bicarbonate reacts with acid. The maximum concentration of dissolved $\mathrm{CO}_{2}$ in Lean MEG will then be the saturation concentration in equilibrium with pure $\mathrm{CO}_{2}$ at the pressure in the tank (atmospheric). The vessel could be purged with fuel gas to reduce $\mathrm{CO}_{2}$ in the Lean MEG. The objective of the re-acidification should mostly be to reduce the alkalinity that reacts to bicarbonate at the MEG injection point to $1-2 \mathrm{mMol} / \mathrm{l}$ in order to mitigate scaling risks.

The type of acid to be used is $\mathrm{HCl}$, the virtue of this acid is that it only adds chlorides; however it has to be carefully monitored and the $\mathrm{pH}$ controlled to a minimum of 6.5 in order to keep a low corrosion rate of the pipeline and MEG injection line. Theoretically, with a carbon steel injection line, the $\mathrm{pH}$ must be above 6 in order to keep the corrosion rate below $0.1 \mathrm{~mm} / \mathrm{y}$. In addition it is recommended to use a corrosion inhibitor (CI) to protect the pipelines and the MEG injection line. Continuous CI injection is required and the dosage must give a concentration in the rich MEG that is sufficient to protect pipeline. A monitoring of CI concentration in both Lean and Rich MEGs must be put in place.

\section{Source of alkalinity to precipitate divalent cations in rich MEG pre-treatment}

One might think that the source of alkalinity must be carbonate. However, in many cases there are considerable amounts of bicarbonate and dissolved $\mathrm{CO}_{2}$ in the rich MEG that react to form carbonate when hydroxide is added. The reactions are:

$$
\begin{gathered}
\mathrm{CO}_{2}(\mathrm{aq})+\mathrm{OH}^{-}(\mathrm{aq}) \\
\mathrm{HCO}_{3}{ }^{-}(\mathrm{aq})+\mathrm{OH}^{-}(\mathrm{aq}) \Longleftrightarrow \mathrm{HCO}_{3}^{-}(\mathrm{aq}) \\
\Leftrightarrow \mathrm{CO}_{3}{ }^{2-}(\mathrm{aq})+\mathrm{H}_{2} \mathrm{O}(\mathrm{l})
\end{gathered}
$$

As a consequence, hydroxide can be added when there are sufficient $\mathrm{CO}_{2}$ and $\mathrm{HCO}_{3}^{-}$in the rich MEG to give a carbonate concentration that can remove the divalent cations. In cases with high $\mathrm{CO}_{2}$ content in the rich MEG, the chemical consumption (on mole basis) will be lower with hydroxide than with carbonate as hydroxide is the stronger base and hence converts more $\mathrm{CO}_{2}$ to $\mathrm{HCO}_{3}^{-}$with the same injection (in mole). The $\mathrm{CO}_{2}$ and $\mathrm{HCO}_{3}^{-}$concentration in the rich MEG is low when the $\mathrm{CO}_{2}$ content in the gas is low, the alkalinity in the rich MEG is low and/or when gas flashing upstream has removed the $\mathrm{CO}_{2}$. The $\mathrm{CO}_{2}$ content in the Reservoir A and Reservoir B is low and this gives a low concentration of 
$\mathrm{CO}_{2}$ in the rich MEG. The mole ratio $\mathrm{Ca}^{2+}+\mathrm{Fe}^{2+}$ to $\mathrm{CO}_{2}+\mathrm{HCO}_{3}^{-}$is e.g. 0.9 to 2.8. Addition of hydroxide would then only remove $30-50 \%$ of these cations and carbonate injection is thus required in order to precipitate all of them. The dominant divalent cations in rich MEG are normally $\mathrm{Ca}^{2+}$ and $\mathrm{Fe}^{2+}$. Calcium originates from the produced water and iron from corrosion. The objective of adding alkalinity in rich MEG pre-treatment is to precipitate these and possibly $\mathrm{Sr}^{2+}$ and in some cases $\mathrm{Ba}^{2+}$ as carbonates. Carbonates are preferred as hydroxides of these cations have a much higher solubility. Only $\mathrm{Mg}^{2+}$ precipitates as hydroxide. $\mathrm{Na}_{2} \mathrm{CO}_{3}$ is used as the alkalinity source.

\section{Lean MEG specifications}

Several aspects must be taken into account when specifying the Lean MEG composition:

- Content of monovalent salts; e.g. chlorides of sodium and potassium, which have small implications for scaling, but affect the Lean MEG viscosity.

- Content of potential scale forming ions; e.g. divalent cations $\left(\mathrm{Ca}^{2+}, \mathrm{Ba}^{2+}\right.$, etc. $)$ and $\mathrm{SO}_{4}^{2-}$.

- The alkalinity that react with $\mathrm{CO}_{2}$ and form bicarbonate and carbonate when equilibrated with the produced gas, must be kept at a minimum.

- Minimum $\mathrm{pH}$ with respect to corrosion of the injection line.

- Oxygen content.

The content of highly soluble salts is usually specified to be maximum 2 or $3 \mathrm{wt} \%$. This is set well below the solubility limits for these salts (in the range 6$8 \mathrm{wt} \%$ depending on composition) in order to give acceptable viscosity of the Lean MEG and take into account lower solubility at low temperatures that might occur during unexpected pressure drops. The content of scale forming ions in the Lean MEG must be small when the formation water production rate increases. If the lean MEG injection line is carbon steel the $\mathrm{pH}$ must be above 6.5 in order to keep the corrosion rate below $0.1 \mathrm{~mm} / \mathrm{y}$. Oxygen in the injected lean MEG may also corrode the injection line, but the corrosion is slow due to the high MEG content and low temperature. Keeping the $\mathrm{O}_{2}$ content to less than $300 \mathrm{ppb}$ and the $\mathrm{pH}$ above 6 should limit the corrosion rate to much less than $0.1 \mathrm{~mm} / \mathrm{y}$. This will also limit the Fe pick up in the Lean MEG to a few ppm. Table 6 shows the lean MEG compositions used in the simulations.

\section{The slip stream calculation}

In order to keep the salt content of the Lean MEG below the target value, monovalent ions from the formation water and the sodium and chloride from the 
Table 6: $\quad$ Lean MEG compositions used in the simulations

\begin{tabular}{|c|c|c|}
\hline Ion & $\mathrm{mmol} / \mathrm{kg}$ & $\mathrm{mg} / \mathrm{kg}$ \\
\hline $\mathrm{Na}^{+}$ & 298.37 & 6859.52 \\
\hline $\mathrm{K}^{+}$ & 4.90 & 191.75 \\
\hline $\mathrm{Mg}^{2+}$ & 0.00 & 0.70 \\
\hline $\mathrm{Ca}^{2+}$ & 0.04 & 1.50 \\
\hline $\mathrm{Ba}^{2+}$ & 0.00 & 0.00 \\
\hline $\mathrm{Sr}^{2+}$ & 0.00 & 0.00 \\
\hline $\mathrm{Fe}^{2+}$ & 0.00 & 0.00 \\
\hline $\mathrm{Cl}^{-}$ & 301.59 & 10692.08 \\
\hline $\mathrm{SO}_{4}{ }^{2-}$ & 0.58 & 55.96 \\
\hline $\mathrm{CH}_{3} \mathrm{COOH} / \mathrm{CH}_{3} \mathrm{COO}^{-}$ & 0.60 & 36.03 \\
\hline Alkalinity & 0.60 & \\
\hline
\end{tabular}

$\mathrm{Na}_{2} \mathrm{CO}_{3}$ and $\mathrm{HCl}$ injections have to be removed from a slip stream. The slip stream has been calculated from

$$
R_{L M} \sum_{1}^{n} C_{i, L M}=R_{R B M}\left(1-\frac{S S}{100}\right) \sum_{1}^{n} C_{i, R B M}+C_{A} R_{A}
$$

where

$\mathrm{C}_{\mathrm{i}}$ is molar ionic concentration (converted to total wt\% for reporting);

$\mathrm{R}$ is rate (mass MEG + water);

SS is slip stream (\% of reboiled MEG rate)

LM denotes Lean MEG;

RBM Reboiled MEG (Lean MEG upstream desalination);

A acid ( $\mathrm{HCl}$ ) added downstream desalination (acid added upstream desalination is one $\mathrm{i}$ in $\mathrm{Ci}, \mathrm{RBM})$.

In the present case, a slip stream rate of $38 \%$ gives $3 w t \%$ salt in the Lean MEG. The expected solids formation in the Desalination (Flash Separator), which is mainly $\mathrm{NaCl}$ and $\mathrm{KCl}$ including the ions from the added chemicals $\left(\mathrm{Na}_{2} \mathrm{CO}_{3}, \mathrm{HCl}\right)$ are equal to $560.8 \mathrm{~kg} / \mathrm{h}$.

\section{Monitoring alkalinity and acid injection}

Careful monitoring is required for both the alkalinity injection in pre-treatment and especially the acid injection to the Lean MEG. Preferentially the alkalinity injection should be dosed according to the amount of divalent cations in the rich MEG. This is probably best measured by measuring the residual concentration of dissolved divalent cations in rich MEG sampled downstream the pre-treatment. The samples must be filtered in order to determine the true concentration of 
dissolved ions. In order to determine the need for acid injection, the alkalinity should be determined in the same samples. The temperature in the pre-treatment is rather low $\left(60^{\circ} \mathrm{C}\right)$. This is a challenge as both iron and calcium carbonate do not nucleate and grow instantaneously. Sufficient residence time is thus required in order to obtain solids that can be effectively removed. In this case, it is expected that iron carbonate precipitation starts upstream the pre-treatment. If iron carbonate does not precipitate to equilibrium, calcium carbonate precipitation may also initiate upstream. Neutralization of Lean MEG should preferentially be based on analyses of the alkalinity and its speciation. It is preferred to make the acid injection to Lean MEG upstream the Lean MEG storage tank. This should reduce the risk of over treating a large volume.

\section{Corrosion}

Some corrosion is expected in the pipelines, which will give increased $\mathrm{Fe}^{2+}$ and alkalinity in the aqueous phase along the transport pipelines. The corrosion rate was set to $0.1 \mathrm{~mm} /$ year for both pipes (ID = 18 inch) and length of $143000 \mathrm{~m}$ each. It was assumed that $15 \%$ of the pipe area was water wetted. This approach is conservative as the low $\mathrm{CO}_{2}$ content in the gas $(0.02 \mathrm{~mol} \%$ in Reservoir A and $0.2 \mathrm{~mol} \%$ in Reservoir B) and low pressure give a moderate corrosivity and a low corrosion rate when a suitable inhibitor is applied. If the lean MEG injection line is carbon steel the $\mathrm{pH}$ must be above 6.5 in order to keep the corrosion rate below $0.1 \mathrm{~mm} / \mathrm{y}$. It has been confirmed that the use of a corrosion inhibitor carried out by the MEG is sufficient to protect the pipeline and MEG injection line; however this corrosion inhibitor has to be selected for this purpose, i.e. with consideration of the MEG - water mixture under the predicted operating conditions. Therefore a dedicated CI selection study has been carried out.

\section{Conclusions}

- In a complex medium of gas, condensates, condensed water, MEG, and formation water of uncertain composition, the prediction of scale risks is not very accurate.

- The simulations performed with Reservoirs A, C, D and E formation waters showed that there is no risk of scaling from bottom hole to well head for both Reservoir A and Reservoir B .

- The main solid that may precipitate in upstream of the MRU is $\mathrm{FeCO}_{3}$. The amount will depend on the corrosion rate of the pipeline.

- The choice of acid to be used to neutralize the Lean MEG is HCl.

- The acid injection to Lean MEG should be performed upstream the Lean MEG storage tank.

- A maximum pH value equal to 7.5 is recommended in the Lean MEG to avoid scaling.

- A minimum pH value of 6.5 is recommended in the Lean MEG in order to keep a low corrosion rate $(0.1 \mathrm{~mm} / \mathrm{y})$ in the pipelines and MEG injection line. 
- Flow rates of acid $\mathrm{HCl}(32 \mathrm{wt} \%)$ should be equal to $1655 \mathrm{~L} /$ day.

- Sodium carbonate, $\mathrm{Na}_{2} \mathrm{CO}_{3}(10 \mathrm{wt} \%)$ is the recommended source of alkalinity to precipitate divalent cations in rich MEG.

- With the anticipated formation water composition and production the sodium carbonate $\left(\mathrm{Na}_{2} \mathrm{CO}_{3}\right)$ injection rate is ca. $43 \mathrm{~m}^{3} /$ day.

- Careful monitoring is required for both the alkalinity injection in pretreatment and especially the acid injection to the Lean MEG.

\section{References}

[1] Anderko, A., Wang, P., Springer, R.D., Lencka, M.M. and Kosinski, J.J., Prediction of mineral scaling in oil and gas production using a comprehensive thermodynamic model. Nace International Corrosion Conference, Paper No. 10129, pp. 1-20, 2010.

[2] Seiersten, M., Brendsdal, E., Deshmukh, S., Dugstad, A., Endrestol, G., Ek, A., Watterud, G., Andreassen, J.P. and Flaten, E.M., Development of a simulator for ethylene glycol loops based on solution thermodynamics and particle formation kinetics. Nace International Corrosion Conference, Paper No. 10131, pp. 1-7, 2010.

[3] Tomson, M.B., Kan, A.T. and Gonigmin, F., Inhibition of barite scale in the presence of hydrate inhibitors, SPE Journal, pp. 256-266, 2005.

[4] Kan, A.T. and Tomson, M.B. (2010) Scale prediction for oil and gas production. SPE Journal, pp. 362-378, 2010.

[5] Haiping Lu., Kan, A.T. and Tomson, M.B., Effect of monoethylene glycol on carbonate equilibrium and calcite solubility in gas/monoethylene glycol/NaCl/water mixed systems. SPE Journal, pp. 714-725, 2010.

[6] Kaasa, B., Sandengen, K. and Østvold, T., Thermodynamic Predictions of Scale Potential, pH, and Gas Solubility in Glycol-Containing Systems. SPE International Symposium on Oilfield Scale, Aberdeen, UK, SPE Paper 95075, pp. 1-13, 2005.

[7] Flaten, E., Seiersten, M. and Andreassen J-P., Induction time studies of calcium carbonate in ethylene glycol and water. Chemical Engineering Research \& Design, 88 (12A), pp. 1659-1668, 2010. 